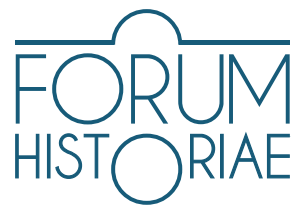

\title{
Beatlephiles and Zappists: Rock Fandom in Communist Czechoslovakia in the Context of the Scene in Brno in the 1980s*
}

\author{
Jan Blüml
}

\begin{abstract}
BLÜML, Jan: Beatlephiles and Zappists: Rock Fandom in Communist Czechoslovakia in the Context of the Scene in Brno in the 1980s.

The history of rock in Communist Europe has been viewed by a number of domestic and foreign authors as a series of events with a dominant political content, either in the form of a general youth revolt or directly in the spirit of anti-communist opposition. In this regard, the present study extends the current simplifying concept with an emphasis on the reception history, including relevant issues related to the typology of listeners and aesthetics. The primary subject of this paper is the reception of two of the most influential representatives of Anglo-American popular music in Communist Czechoslovakia, these being the Beatles and Frank Zappa. The reception of both artistic subjects is reflected in the specific space of the Brno scene of the 1980s, within the framework of the artist fan clubs which had no parallel anywhere else in the country. The study demonstrates the specifics of American and British rock fandom in the given time and space and challenges the long-held narrative about the supremacy of the political functions of rock behind the Iron Curtain.
\end{abstract}

Keywords: The Beatles, Frank Zappa, Czechoslovakia, Communism, rock music, rock fandom, Brno, Moravia, reception history

DOI: https://doi.org/10.31577/forhist.2020.14.2.3

$\mathrm{T}$ he present study examines the reception of Anglo-American popular music in the specific environment of the South Moravian metropolis of Brno in the period of late normalization. The topic is analysed through the history of fan clubs which were established in the second largest city of the Czech Socialist Republic ${ }^{1}$ during the 1980s and whose systematic and long-term functioning at that time at least according to the current state of knowledge - was unparalleled anywhere else in the country. This was first the fan club of the British band the Beatles formed in 1982 in Hrušovany, near Brno, and second, the fan club of a representative of rock in the United States, Frank Zappa, established in Brno in 1986. Both institutionalized communities, concentrated around musical idols from the West, shared roots in the Czechoslovak and Moravian rock tradition. Additionally, each of them benefited in an original way from the possibilities provided by the Brno scene at that time. Based on archival documents and interviews with the protagonists in the described events, the article maps out the activities of both

* This study is a result of research funded by the Czech Science Foundation as the project GA ČR P410/20-24091S "Brave New World: Youth, Music and Class in Czech Post-socialism".

1 As a member state of the federal Czechoslovak Socialist Republic in the years 1969 - 1990. In 1980, Brno had almost 400,000 inhabitants, and the capital city of Prague had approximately 1,100,000 inhabitants. 
clubs, not only in the light of contemporary cultural policy and the tradition of Czechoslovak rock fandom, but also taking into account the specific functions that the Beatles and Frank Zappa fulfilled within Czechoslovak culture over the long run. ${ }^{2}$

Both the Beatles and Frank Zappa became the subject of original Czech monographs during the Communist era, which did not apply to anyone else in the field of foreign rock. In the first case, the authors were Jiří Černý and his wife Miroslava Černá (Poplach kolem Beatles, 1966) and Antonín Matzner (Beatles: výpověd' o jedné generaci, 1987); in the second case, it was Petr Dorůžka (Šuplík plný Zappy, 1984). The first LP by the Beatles was officially released in Czechoslovakia in 1969 (A Collection of Beatles Oldies but Goldies), followed by several others. ${ }^{3}$ The release of music by the Mothers of Invention was planned by the Supraphon Gramophone Club as early as 1972, ${ }^{4}$ while the first and last official medium (cassette tape) with Zappa's music appeared only in $1977 .{ }^{5}$ For many listeners, the artists in question represented the counterparts or archetypes of rock of the 1960s: American and British style - the first rational and critically focused on the present, the second intuitive and with a nostalgic glance to the past. ${ }^{6}$ This confrontation actually took place directly through Zappa's album We're Only in It for the Money (1968) parodying the fantastic world of Sgt. Pepper's Lonely Hearts Club Band (1967) by the Beatles.

The polarization of the mainstream band the Beatles and the underground artist Frank Zappa took on a special meaning in the Czechoslovak reception of popular music during the normalization process after the occupation of Czechoslovakia by the Warsaw Pact troops in August 1968. While the Beatles became part of the so-called official scene, for example, through nostalgic songs by pop singers such as Karel Gott, ${ }^{7}$ through presentations in television series, ${ }^{8}$ through propaganda films such as Atentát na kulturu (1977) or through ironic allusions in materials such as Úkoly české alternativní hudby (1979) by Josef Vlček, Frank Zappa acquired the status of an iconic figure of underground and alternative rock, where he inspired groups such as the Plastic People of the Universe ${ }^{9}$ or personalities such as Mikoláš Chadima. ${ }^{10}$ Despite a number of natural overlaps, in terms of the Czechoslovak reception of Anglo-American popular music, in this sense, one can actually register two relatively distinctive audiences - "Beatlephiles" and "Zappists" - more or less defining themselves in relation to one another in terms

2 With its emphasis on the history of music reception, including relevant aesthetic and other issues, the article is based in the field of musicology. Its primary ambition is not to examine fandom in terms of the formation of social and other identities, as other disciplines, including Media Studies, do. SHUKER, Roy. Popular Music: The Key Concepts. London and New York : Routledge, 2005, pp. 98-99.

3 DIESTLER, Radek. Cizí desky v zemích českých, aneb, Ochutnávka na samém kraji útesu. Praha : Popmuzeum, 2008.

4 Z domova. In Melodie, 1972, Vol. 10, No. 6, p. 172.

5 DIESTLER 2008.

6 ŠŤASTNÝ, Jaroslav. Zappa jako „vážný skladatel“. In DORŮŽKA, Petr. Šuplík plný Zappy. Praha : Volvox Globator, 2016, pp. 209-210.

7 See the list of songs at Brouci.com, https://rb.gy/j1imry.

8 For instance, Inženýrská odysea (1979), Dobrá voda (1982) or My všichni školou povinní (1984).

9 RIEDEL, Jaroslav. Plastic People a český underground. Praha : Galén, 2016, p. 123.

10 Cf. CHADIMA, Mikoláš. Alternativa I. Praha : Galén, 2015; CHADIMA, Mikoláš. Alternativa II. Praha : Galén, 2018. 
of aesthetics, especially in relation to humour and irony in rock, but partly also by their attitudes to the social functions of music.

It was not just Zappa, however, whose name was strongly politicized in the Czech popular music context, at least by certain social circles. The second cult figure, unparalleled among the idols of Anglo-American popular music in Czechoslovakia, was the founder of the Beatles, John Lennon, whose tragic passing on 8 December 1980, was described as the "death of the century" by the dissident and future president Václav Havel: "Perhaps because it so urgently transcends itself; as if there was latently present more tragically distinctive contexts, problems and crisis aspects of today's world than in any other incident of this kind."11 This link to the well-known figure of anti-communist opposition also existed in the case of Frank Zappa, whom Havel met personally immediately after the Velvet Revolution in January 1990. After Zappa's death on 4 December 1993, Havel was the author of the musician's obituary, where he called the American artist the "God" of Czech underground, a great rock personality and his friend. ${ }^{12}$ The unique process of canonization of both artistic subjects was later underlined by extraordinary events, such as the exhibition of the Czech Museum of Music Beatlemania! (2010) $)^{13}$ and the interdisciplinary conference The Phenomenon of Zappa (2013) held by the Department of Czech Studies, Faculty of Arts, University of South Bohemia. ${ }^{14}$

The following comparative paper on both Moravian fan clubs based in Brno will be closely connected with the broader issue of the reception of Anglo-American popular music in Czechoslovakia in the aforementioned sense. Regarding the international discussion on the functioning of Western rock in European Communist countries, the text primarily follows Ewa Mazierska's current critique of the "Cold War Paradigm", ${ }^{15}$ which rejects the simplistic perception of Eastern Bloc rock history as established in the early $1990 \mathrm{~s},{ }^{16}$ this being a view which attributes the genre primarily with revolt and anti-communist attitudes, for example in the spirit of Leslie Woodhead's later book How the Beatles Rocked the Kremlin. ${ }^{17}$ In this regard, the article seeks to demonstrate that Anglo-American rock music, in many of its genre variations (even ideologically quite contradictory), functioned behind the Iron Curtain primarily as an aesthetic object; moreover, often under the auspices and with considerable support of official institutions. It additionally aims to display the extent to which Moravian rock culture differed from that of the capital city of Prague - the central scene which through selected local witnesses served as one of the starting points for the narrative

11 HAVEL, Václav. Dopisy Olze (Spisy 5). Praha : Torst, 1999, p. 232.

12 The original text in English (The New Yorker, December 20, 1993) was translated and published in samizdat Zapparition, No. 1, later also in Zappostrophe, 1996, No. 45, p. 5.

13 See the catalogue Beatlemánie! Praha : Národní muzeum, 2010.

14 See PAPOUŠEK, Vladimír - SKALICKÝ, David (eds). Fenomén Zappa. Praha : Akropolis, 2016.

15 MAZIERSKA, Ewa. Introduction. Popular Music in Eastern Europe: Breaking the "Cold War Paradigm". In MAZIERSKA, Ewa (ed.) Popular Music in Eastern Europe. London : Palgrave Macmillan, pp. 3-4.

16 Especially by RYBACK, Timothy. Rock Around the Bloc: A History of Rock Music in Eastern Europe and the Soviet Union, 1954 - 1988. New York : Oxford University Press, 1990, and RAMET, Sabrina Petra (ed.) Rocking the State: Rock Music and Politics in Eastern Europe and Russia. Boulder : Westview Press, 1994.

17 WOODHEAD, Leslie. How the Beatles Rocked the Kremlin. The Untold Story of a Noisy Revolution. New York : Bloomsbury, 2013. 
of the "revolutionary role of the electric guitar in Communist Europe" presented in Timothy Ryback's paradigmatic work Rock Around the Bloc (1990). ${ }^{18}$

\section{“The Beatles' and Ex-Beatles' Music Friends Club": Between the Cult of John Lennon and the Brigades in "Action Z" (1982 - 1990)}

Fan clubs of foreign popular music stars began to emerge in Czechoslovakia especially in the liberal atmosphere of the second half of the 1960s, as evidenced by magazines such as Melodie and Mladý svět. For example in 1969, the latter published a complaint about the lack of seriousness of the official Czechoslovak Beatles fan club by the reader Zdena Homolková from Prague. Apart from the entry pass card, the author of the complaint had received no information during her four-year membership and expressed her outrage even in a letter sent to the Beatles' central fan institution in London. ${ }^{19}$ Another magazine with a focus on fan clubs since mid-1969 was Pop Music Expres: in the twelfth issue of the same year, for instance, the address of the "Official Beatles Fan Club the Czechoslovak", led by Pavel Chaloupka and based in the North Bohemian town of Ústí nad Labem, was published. ${ }^{20}$ As far as the United States scene was concerned, in the second half of the 1960s there were fan clubs for Paul Anka, Carl Perkins, and up until 1969 also a fan club for Elvis Presley in Prague; ${ }^{21}$ there is no evidence of the existence of a Frank Zappa fan club from this period.

Similarly to Pop Music Expres, which was abolished after a short existence in 1968 - 1969, fan clubs of Anglo-American popular music stars soon succumbed to normalization pressure and disappeared as well. Their partial return occurred only in the specific conditions of the 1980s, with the gradual rehabilitation of rock in all its forms and mostly as a result of the activity of the second rock generation - a generation which did not actively experience the "golden sixties" but learned about it from parents or older siblings and friends. The above-mentioned generational feature did not concern only Eastern Bloc countries, however, but characterised, in a way, popular music globally. The original British fan club of the "Fab Four" ended, for example, after the band broke up in the early 1970s, and one of its successor organizations became the London Beatles Fan Club founded in 1988 by Richard Porter (b. 1963) - a devoted fan of the group since the mid-1970s, who was significantly affected by the death of John Lennon and who established the club after several years of musical correspondence acquaintances. ${ }^{22}$ Similar starting points also characterised the founders of the Hrušovany Beatles fan club, which tested the possibilities of official existence at the cost of concessions to contemporary cultural-political norms.

One of the direct impulses for founding the club was the aforementioned death of John Lennon on December 8, 1980. As Timothy Ryback writes, the assassi-

18 Cf. RYBACK, Timothy. Rock Around the Bloc Revisited: Researching Pop Culture in Eastern Europe and the Soviet Union Then and Now. In BLÜML, Jan - KAJANOVÁ, Yvetta - RITTER, Rüdiger (eds.) Popular Music in Communist and Post-Communist Europe. Berlin : Peter Lang, 2019, pp. 13-22.

19 HOMOLKOVÁ, Zdena. Fan Club Beatles. In Mladý svět, 1969, Vol. 11, No. 36, p. 21.

20 Fan Cluby. In Pop Music Expres, 1969, Vol. 2, No. 12, p. 11.

21 ČERNOCKÝ, Pavel. Takoví jsme byli. Praha : Nakladatelství BVD, 2019, p. 144.

22 See London Beatles Walks with Richard Porter, https://beatlesinlondon.com/richard-porter/. 
nation aroused an extraordinary response not only in the West but also across the countries of Communist Europe. The coverage of the official media often differed, as Lennon was celebrated as a progressive artist with left-wing views but was cursed as a celebrity of Western popular music. ${ }^{23}$ On December 10 , the press body of the Central Committee of the Communist Party of Czechoslovakia, Rudé právo, printed a short mystifying report "He did not sign an autograph, he received a bullet"; ${ }^{24}$ consequently, on December 18, a brief reflection on Lennon's death followed, with an emphasis on the singer's leftist thoughts and with excerpts from the translated lyrics of the song Imagine. ${ }^{25}$ The death of the famous ex-Beatle was also reported by Mladá fronta ${ }^{26}$ and other dailies, as well as by the main popular music magazine Melodie. ${ }^{27}$ Texts about Lennon also eventually appeared in unofficial literature, including the well-known underground samizdat Vokno. ${ }^{28}$

The death of John Lennon invoked a number of spontaneous reverential events by fans in many places across Czechoslovakia: in Prague, for example, it was the embankment, the park near Čertovka, and especially Velkopřevorské náměstí (Grand Priory Square) in the Kampa district, where in the mid-December 1980, on one of the adjacent walls, a symbolic grave (the so-called Lennon Wall ${ }^{29}$ was painted. The square consequently became a space where annual commemorative events took place, which in the second half of the 1980s turned into political demonstrations. ${ }^{30}$ In 1982, a Lennon monument was erected in Liberec, and in the same year, an attempt to install a bust of John Lennon in Karlova Ves near Bratislava took place. ${ }^{31}$ In later years, Beatles' fans established similar reverential spots in Zlín (then Gottwaldov), Plzeñ ${ }^{32}$ or Karlovy Vary. ${ }^{33}$ At the end of 1981, an analogous place existed in Brno for a short time, specifically, a wooden cross with Lennon's photo on the wall in the Denis Gardens under Petrov hill. A year later, in September 1982, Jan Břečka and a secondary school classmate tried to restore the monument; they hammered a memorial poster into one of the niches on the wall next to the Cathedral of Sts. Peter and Paul. This monument did not last long on the site either. The pietà for John Lennon in Brno gained an exceptional dimension when Břečka arranged a mass for the founder of the Beatles on December 5, 1982, at the parish office of the aforementioned cathedral: "It was so easy that I couldn't believe it! True, the pastor kindly rejected the notes of 'Help' and 'A Day in the Life' imposed by me - the parishioners were allegedly used to different songs - but otherwise he wrote down and confirmed everything. [...] I don't want to brag about it here, but I don't know of any other event of this kind that would have been settled anywhere else in the country in the early 1980s - and most importantly, that would

23 RYBACK 1990, pp. 191-193.

24 Nedal autogram, dostal kulku. In Rudé právo, 10 December 1980, p. 7.

25 kz. Malé zamyšlení. Vražda č. 701. In Rudé právo, 18 December 1980, p. 5.

26 išt. John Lennon: vyměnil život za autogram. In Mladá fronta, 10 December 1980, p. 5; ČECH, Karel. Smrt čtyřhlavého Orfea. In Mladá fronta (Víkend), 10 January 1981, p. 8.

27 ČERNÝ, Jiř́i. Cesta do marmeládového nebe. In Melodie, 1981, Vol. 19, No. 2, p. 46.

28 JIROUSOVÁ, Věra. V Praze na Kampě je hrob Johna Lennona. In Vokno, 1981, Vol. 3, No. 5, pp. 80-82.

29 BLAŽEK, Petr - LAUBE, Roman - POSPÍŠIL, Filip. Lennonova zed'v Praze. Praha : Ústav pro soudobé dějiny AV ČR, 2003, pp. 10-11.

30 BLAŽEK - LAUBE - POSPÍŠIL 2003, pp. 18-52.

31 BLAŽEK - LAUBE - POSPÍŚIL 2003, pp. 27-28.

32 BLAŽEK - LAUBE - POSPÍŠIL 2003, p. 46.

33 BLAŽEK - LAUBE - POSPÍŚIL 2003, pp. 27-28. 
have actually taken place. Although it was just an ordinary Mass, John's name was actually heard at it." ${ }^{\prime 34}$ In January 1981, the later founder of the club in Hrušovany, Petr Dorňák (b. 1955; today a journalist using his original name Petr Gratias, which will be used in the following text), presented a two-part programme with recorded music about Lennon in the cultural hall in Černovice; a month later, on February 2, 1981, the Brno Small Theatre of Music also presented a show about Lennon. ${ }^{35}$

As Petr Gratias recalls, he was deeply touched by John Lennon's death, which led to thoughts about establishing a club dedicated to the "Fab Four", along with other friends whom he met with regularly at Saturday's unofficial record exchanges in the city centre under the Janáček Theatre. Gratias's friend Cyril Fanta (1948 1990), seven years older, was a crucial personality connected mainly with the administrative management of the club. According to Gratias, he was a decent, kind, and helpful man, a company clerk who loved the Beatles and who also excelled in organizational talent, had a business spirit, and could find or arrange anything. ${ }^{36}$ Jan Břečka recalls Fanta from the records exchanges as a peculiar figure, usually with a black leather briefcase, crammed with high-quality black-and-white photographs not only of the Beatles. His flat usually served as a base where slides were taken and the music to be used in the club's programmes was recorded late into the night. ${ }^{37}$ According to the renowned Czech journalist Jiř́i Černý, Fanta's home was more reminiscent of a Beatles' museum than a civil flat. Černý's memory dates back to the beginning of 1990, when Cyril Fanta died, and when his friends in the Rajhrad ceremonial hall allowed him to play Mr. Moonlight, his favourite song recorded by the Liverpool quartet. ${ }^{38}$

If Cyril Fanta ensured the club's administration, Petr Gratias focused mainly on its dramaturgy, the key part of which was educational programmes with recorded music accompanied by spoken word and audio-visual materials (in Czech the socalled listening programmes). From his first meetings with Gratias, Jan Břečka recalls his deep voice, George Harrison's visage from 1970 and an insightful talk about the life of the Beatles. ${ }^{39}$ Gratias, a graduate of the Brno Polygraphic Secondary School, was employed as a proof-reader at Rudé právo until 1992 and loved 1960s and 1970s rock (but would take primarily the Beatles "to a desert island" if necessary). ${ }^{40}$ He represented a specific type of recipient of popular music, which was formed under the musical changes at the turn of the 1970s. He was a recipient who in no way fit with the conservative idea still prevalent in the 1960s, for whom listening to popular music was a mere transition phase to understanding the "higher values" of classical music over the course of the natural process

34 BŘEČKA, Jan. Jak jsem potkal Beatles, manuscript, Brno 2008. Archive of J. Břečka.

35 JANÁČKOVÁ, Libuše. Malé divadlo hudby a poezie v Brně 1962 - 1995. Brno : Ústav hudební vědy FF MU, 2017, p. 222.

36 Interview with P. Gratias from June 2020, author's archive.

37 BŘEČKA 2008.

38 ČERNÝ, Jiří. Beatlemanie česky i slovensky. In Načerno: internetové stránky Jiřího Černého, 8 September 2008, https://rb.gy/vl2yvj

39 BŘEČKA 2008.

40 Interview with P. Gratias from June 2020, author's archive. 
of maturing, ${ }^{41}$ namely by connecting traditional attributes of classical music reception with admired "art rock". According to Gratias, listening to popular music assumed a necessary preparation in advance, including a knowledge of relevant historical and aesthetic contexts and song lyrics. Additionally, the autonomous listening function and respect for the totality of the musical work were essential - in the case of art rock specifically for the (concept) LP record: "If I feel like Pink Floyd or King Crimson, I'll play the whole albums. [...] I was an LP-man. I've never been into tapes or cassettes, nor have I recorded from the radio. The record was an artefact for me, even at the cost of it being more expensive." ${ }^{\prime \prime 2}$

In addition to Cyril Fanta and Petr Gratias, the founders of the fan club also included the aforementioned Jan Břečka (b. 1966). He described the inaugural meeting of the club on November 20,1982, in the lounge of the restaurant Na Benátkách in Brno-Židenice with regard to the overall character of the emerging fellowship: "I remember going to the meeting with the uplifting feeling that I was becoming part of a community of Beatles lovers that accepted me as an equal, although I was much younger than the others. For the meeting, I properly 'fashioned' myself with my old grandfather's coat, beads on my neck, leather pendants and a cross, longer hair, just 'hippie', as it should be. Then I was a little surprised that apart from the real 'hairies' [máničky] Petr Dorňák and Bohouš Šašecí (both in 'Plastic Ono Nuclear Band' T-shirts), everyone else looked like completely ordinary 'guys' with their wives, moreover, as I later found out, many of them were members of the Communist party." ${ }^{\prime \prime 3}$ Cyril Fanta, in whose home town of Hrušovany near Brno (at that time a village with almost three thousand inhabitants and less than 20 kilometres from Brno) the club was finally established, was also a member of the Communist Party. As Petr Gratias confirms, it would have been quite difficult to establish such a club directly in Brno at the time. ${ }^{44}$ The club existed until 1990, when it slowly and quietly "disappeared into the lost", ${ }^{45}$ not only due to general cultural transformations, but mainly due to the premature death of the leading integrating personality of Cyril Fanta.

The originally intended name "The Beatles' and Ex-Beatles' Music Friends Club" had to be abandoned due to the cultural-political norms of the cover organization, which was the local Educational Institute (Osvětová beseda). Accordingly, the community was given a neutral label "The Friends of Music Club at OB Hrušovany near Brno". As an official organization, the club was subject to appropriate legislation: it elected a chairman, two vice-chairmen, an executive-secretary, a treasurermanager and an audit committee; every first Saturday of the month, a committee meeting was supposed to be held. In addition to paying membership fees in the amount of 50 crowns, members were also obliged to work five brigade-hours

41 BLÜML, Jan. Progresivní rock: světová a československá scéna ve vybraných reflexích. Praha : Togga, 2017, pp. 269-270.

42 Interview with P. Gratias from June 2020, author's archive.

43 BК̌EČKA 2008.

44 Interview with P. Gratias from June 2020, author's archive.

45 B ̌̌EČKA 2008. 


\section{KLUB PŘÁTEL HUDBY}

při OB Hrušovany u Brna

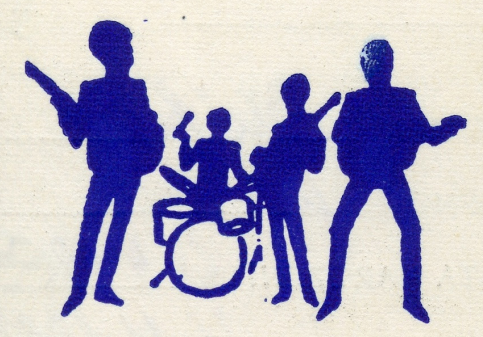

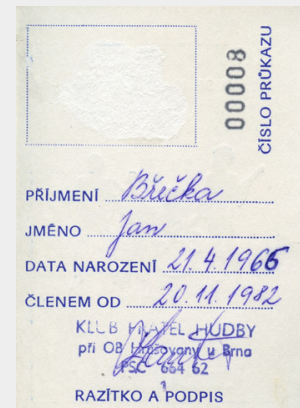
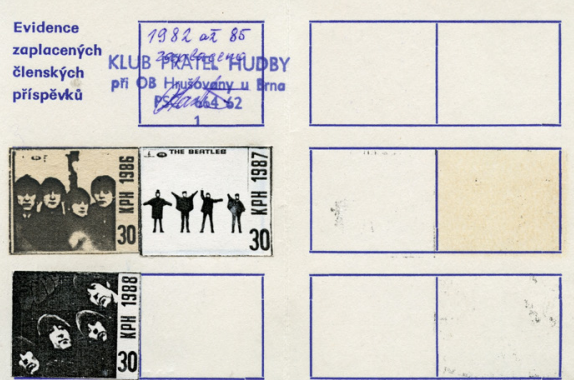

Figure 1 (left). Membership card of the Beatles fan club. Archive of J. Břečka.

Figure 2 (above). Membership card of the Beatles fan club with the evidence of paid fees. Archive of J. Břečka.

\section{ČLENSKÝ PRÜKAZ}

per year in "Action Z", organized by the Hrušovany National Committee; at the end of 1983, the club reported a solid result of 105 hours worked. ${ }^{46}$

The membership base of the club was originally comprised of fans from Brno and its surroundings; however, over the course of the decade it gradually expanded with members from more distant parts of Moravia and Bohemia through pen-pal acquaintances and other contacts. In 1984, when the age for joining the club was lowered from 18 to 16, the membership base included 30 people. By the end of the following year it was already 64 members; at the end of March 1988, the club had 144 members, and by the end of the 1980s, it had grown to 181 members. ${ }^{47}$ Let us add that it was an active club for the entire duration, where members were gradually accepted, but also expelled, for example, for non-fulfilment of obligations, but also at their own request (due to lack of interest in regular "meetings", participation in brigades, etc.). In order to promote personal contacts and exchange information, the club regularly published the members' addresses in its fanzine. Thanks to this, there is a clear picture as to what kind of impact this seemingly inconspicuous initiative led by several Beatles' lovers at the specific time of late normalization and in a space outside the centre, had. The directory from 1986, which contains 104 addresses, is dominated by members from the Brno region, but one can also find the South Moravian towns of Břeclav or Znojmo and moving to the north, towns such as Olomouc, Jeseník, Ostrava, Třinec, Český Těšín or Karviná. Outside Moravia, the club had members in East Bohemian Hradec Králové, West Bohemian Plzeň, or in South Bohemian České Budějovice, Strakonice, Písek, Kardašova Řečice or Černá v Pošumaví; fans from Prague showed up later. In 1986, the oldest member of the club was 41 years old and the youngest

46 The following information regarding the club activities comes largely from the fanzine Občasník, which is stored in the private archive of J. Břečka.

47 BŘEČKA, Jan. Ohlédnutí za starými časy. In Beatles včera a dnes, 1995, Vol. 2, No. 1, p. 10. 
was 16 years old. Most of the members belonged to the second rock generation (69 members in total); specifically, these were fans born in the 1960s, therefore between 17 and 26 years of age in 1986. There were 14 women among the club members in 1986.

From the very beginning, the primary activity of the club consisted of presentations of educational listening programmes based on the model of Jiří Černý's "anti-discotheques", ${ }^{48}$ but also in accordance with the long tradition of Czechoslovak Music Theatres. ${ }^{49}$ As early as 1983, the club presented a two-part programme about John Lennon by Petr Gratias, as well as Concert for Bangladesh and Paul McCartney - Wings. The participation of almost 100 paying spectators in each of these programmes, including reruns, i.e. reaching the maximum capacity of the U Nádraží wine bar in which the club activities took place, represented an immediate success. Additionally, the interest fused several generations, when the age limit of the visitors ranged from 14 to 60 years of age. Representatives of the Local National Committee also took part in the first premiere about Lennon with an atypical dramaturgy, as Jan Břečka recalls: "I don't know anyone who, before or after, included 'songs' from the very first solo albums of John and Yoko in such a programme (I mean 'Unfinished Music No. 1 - Two Virgins', 'Unfinished Music No. 2 - Life with the Lions' and 'Wedding Album'). The author of the programme, Petr Dorňák, did so, and I have to admit that the first listening was difficult even for us, the Beatles fans. Several local politicians came to the June premiere, I don't know, whether out of duty or curiosity, wondering what kind of club this guy Fanta actually ran. I will never forget the expression on their faces during the tiring demonstrations of Yoko Ono screaming or over the course of the recording of the 'wedding-album' calling of John and Yoko."50
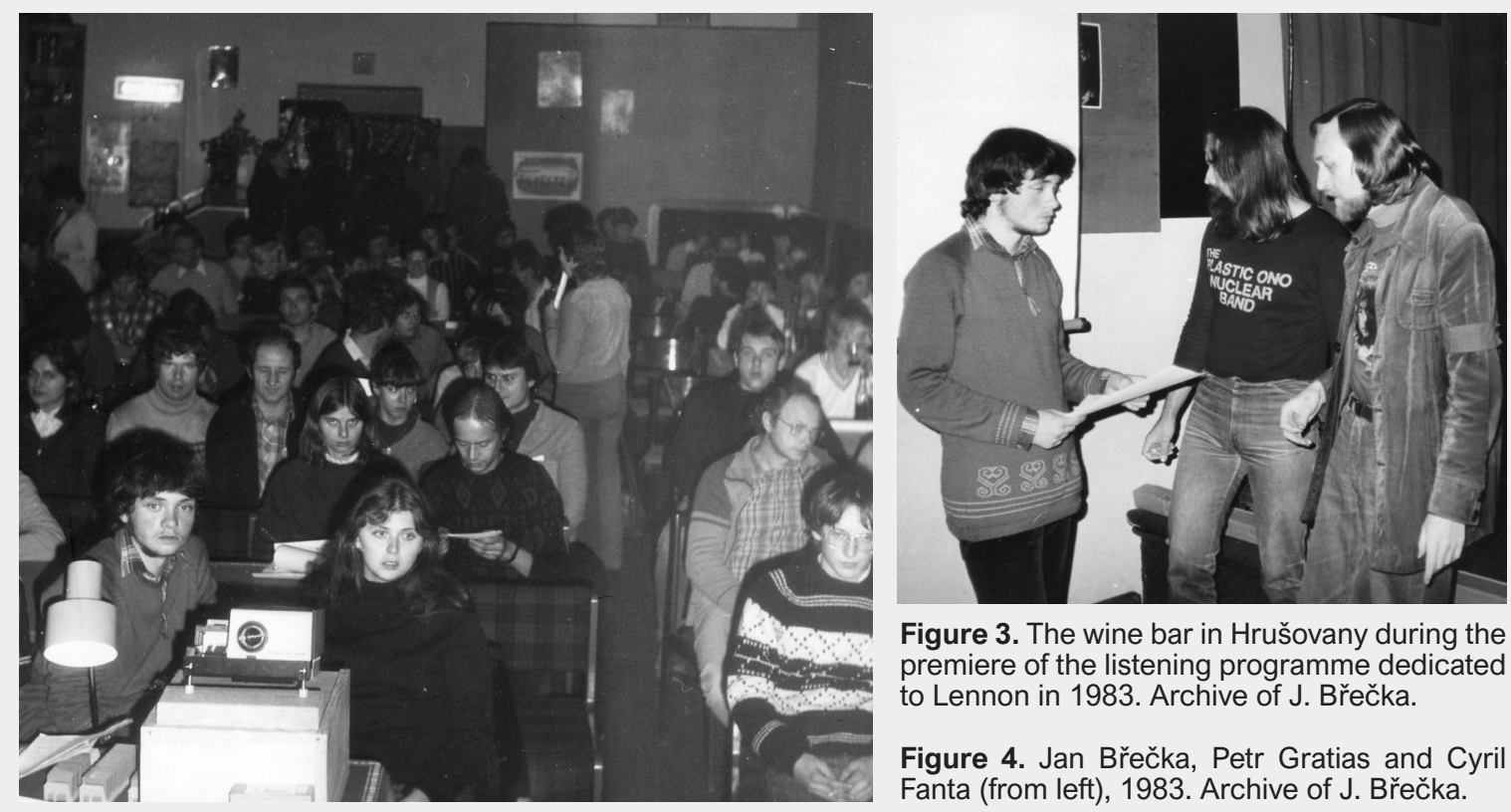

Figure 3. The wine bar in Hrušovany during the premiere of the listening programme dedicated to Lennon in 1983. Archive of J. Břečka.

Figure 4. Jan Břečka, Petr Gratias and Cyril Fanta (from left), 1983. Archive of J. Břečka.

48 RIEDEL, Jaroslav. Kritik bez konzervatoře. Praha : Galén, 2015, p. 223.

49 Založení Divadla hudby. In Historie společnosti Supraphon, https://rb.gy/bhtkcn

50 BŘEČKA 1995, p. 10. 
Starting in 1984, Jiří Černý was a regular guest at the club, with listening programmes largely focused on the Beatles. The fact that the British band's output was still well received in the mid-1980s is confirmed by the evaluation of Jiří Černý's five-part series, presented during April and May 1985. A report from the club fanzine states that these shows attracted a great many people, with the number of visitors considerably exceeding the very limits of the wine bar. In addition, the Beatles allegedly once again proved to be attractive to all generations, with the youngest visitor being ten years old and the oldest 66 years old. The club contributed to the show's success by providing nearly 1,000 black-and-white and colour slides; therefore, "the Beatles series strengthened the club's position, broadened its audience and increased its prestige."

Given the general demand for information on Western rock music, as well as due to current changes on the music scene, the club gradually expanded its scope to other areas. Apart from the Beatles, Jiří Černý himself provided the club with programmes about British art rock (Genesis, Pink Floyd, Jethro Tull), later also about hard rock (Led Zeppelin, Deep Purple), as well as about various historical and contemporary groups and personalities, such as Dire Straits, Bruce Springsteen, Talking Heads, Bob Dylan, Queen, U2, Peter Gabriel, Simon and Garfunkel, Manfred Mann, Frank Zappa, Okudzhava, Vysotsky, the Sex Pistols or the Velvet Underground. Especially at the end of the 1980s, the dramaturgy of the club reached considerable breadth thanks to new arriving younger members interested mostly in then fashionable heavy metal. This genre appeared not just in programmes with recorded music, but also as part of the club's new medium of concerts. In terms of live music, the club organized five continuations of the Hrušovanské rockování festival in the years 1984 - 1988, where, apart from local bands, well-known guests from Prague, such as Precedens, Vítkovo kvarteto or Mama Bubo, performed. It was specifically this event that entailed an extraordinary organizational burden and which mostly resulted in a "financial crash", which the club's management eventually compensated for with other activities. The audit carried out, for example, in 1987, indicates that the club's income for the previous year 1986 was 32052 crowns (the amount was the cash balance from 1985, membership fees plus registration fees, tickets sold and subsidies from the Educational Institute), and the expenditure of 30943 crowns (payment for productions, copyrights, travel expenses, posters, slides, paper, postage, rent, etc.). The final balance, therefore, was positive, with this also being the case for other years of operation..$^{52}$

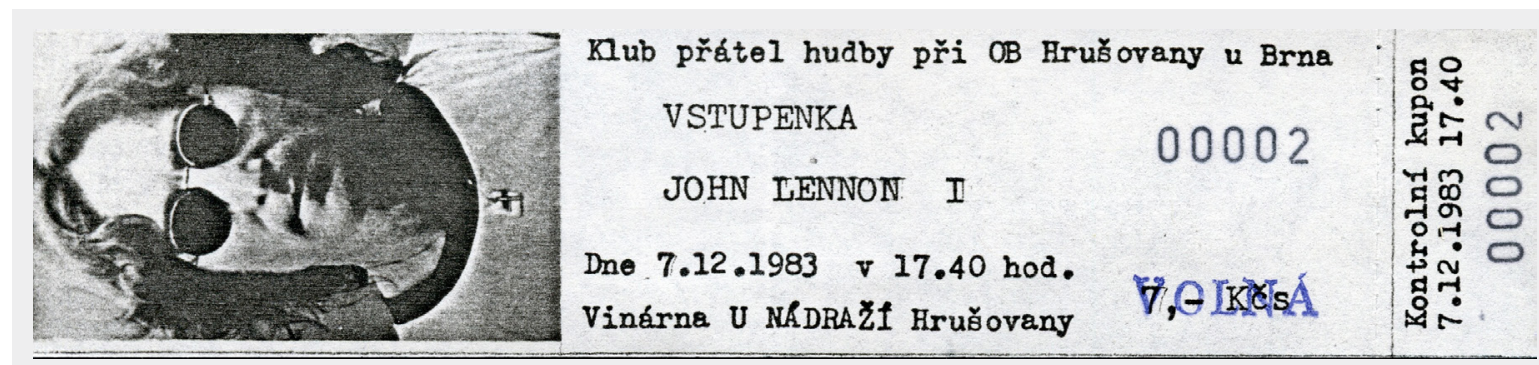

Figure 5. Ticket to the listening programme dedicated to Lennon. Archive of J. Břečka

51 ŠAŠECÍ, Bohumír. 5x The Beatles. In Občasník, 1985, Vol. 2, No. 2, p. 2.

52 Občasník, 1987, Vol. 5, No. 1, p. 2. 
At present, the club's fanzine Občasník best testifies to the functioning of the institution. Although the historian Miroslav Vaněk, referring to information from the samizdat Oslí uši from 1990, states that the very first domestic purely musical samizdat was the Brno magazine Druhá strana, ${ }^{53}$ the first issue of which was published in October 1985, the primacy actually goes to Občasník, the first issue of which appeared in autumn 1983. The fanzine is currently not registered, however, in the Prague Libri Prohibiti library and is only briefly mentioned in a thesis by Pavel Kadlec on the underground community in Dolní Kounice near Brno in the 1980s. Kadlec makes mention of it, along with additional unofficial publications from the Brno region, such as Revue 88 or the music samizdat $\check{S}$ ot from the late $1980 \mathrm{~s}^{54}$

Twenty-three issues were published over the period 1983 - 1989; with the exception of the first and last year, four issues were published annually. Cyril Fanta contributed to the publication of Občasník with a cyclostyle thanks to his acquaintances and ties to official institutions. The most prominent authors were Petr Gratias and Bohumír Šašecí, both employees of the state company Tisk. Although the club could not directly refer to the Beatles by its name, it expressed its affiliation with the English group with at least a small logo at the top of the cover, specifically through a typical silhouette of the performing band, immediately recognizable to fans. They also, of course, used photographs on the covers, which in most cases showed the Beatles or one of its members; only in a few cases did someone else appear here (Elvis Presley, Bob Dylan, Bruce Springsteen, Yoko Ono). From just three pages in the first issue of 1983, in the coming years, Občasník expanded to 22 pages in the third issue of 1986; the average fanzine range was usually around 12 pages. Similar to other semi-official or unofficial magazines focused on popular music and rock of the normalization era (typically the Jazz Section's bulletin Jazz), Občasník tended to have a broader genre scope, as was the case with the aforementioned listening programmes, on the basis of which thematic articleseries were published.

The first major series, published in 1983 - 1986, was dedicated to the cult figure of John Lennon. In addition, Lennon was mentioned in other texts, including celebratory commemorations, such as Requiem for J. W. Lennon by Petr Gratias. From 1986 to 1988, Lennon was followed by a series on Ringo Starr and the next was on George Harrison. Other articles focused on diverse issues related to the Beatles: the band's history in dates, a series on the so-called bootlegs, unknown recordings, foreign as well as domestic cover versions, Beatles EPs with attempts at an analytical commentary and aesthetic evaluation. Apart from the Beatles, the periodical featured additional studies on the Doors, Leonard Cohen, Bruce Springsteen, Tom Waits, U2, Syd Barrett, Deep Purple, Bulat Okudzahava, and Scottish bands such as Simple Minds, Cocteau Twins, and Marillion. The authors of Občasník usually drew the information from the British magazines Melody

53 VANĚK, Miroslav. Byl to jenom rock'n'roll? Hudební alternativa v komunistickém Československu 1956 1989. Praha : Academia, 2010, p. 529.

54 KADLEC, Pavel. Undergroundová komunita 1980 - 1991 v Dolních Kounicích: př́padová studie neoficiální kultury na malém městě. Brno : Ústav hudební vědy FF MU, 2012, pp. 26-27. 
Maker and New Musical Express, as well as from the West German Musikexpress/ Sounds, and the Polish Panorama, not unlike the professionals from Melodie.

\section{"Frank Zappa Fan Club, Brno, Czechoslovakia": Zappists in the Under- ground in the Era of "Glasnost" (1986 - 1991)}

While the first news about the Beatles came to Czechoslovakia in 1963, ${ }^{55}$ it was not until the last third of the 1960s that the local audience became slowly acquainted with Frank Zappa. This was mainly due to the Primitives Group in Prague, which was one of the first to focus on American avant-garde and which was later followed by the Plastic People of the Universe. ${ }^{56}$ Around 1968, when the Beatles already enjoyed the recognition of a relatively wider strata of Czechoslovak society, the renowned musicologist Josef Kotek warned against Frank Zappa and the Western underground. In a report from the Internationale Essener Song Tage, he drew attention to the protests of Western European youth transforming into provocations, and in this connection also mentioned Zappa, who "did not publicly masturbate on the Essen stage (in the United States, he did it allegedly just one time)" but did devote a good half-hour to an inspirational reflection on masturbation in music at the press conference. ${ }^{57}$ Although Kotek, in another article from 1969, negated the possibility of the Western underground transferring to Czechoslovakia, ${ }^{58}$ the change in the political course after the occupation in August 1968 created the conditions for a specific domestic form of the underground with more or less obvious attributes of anti-regime opposition. In this context, Frank Zappa's name resonated not only thanks to the artist's creative exclusivity and distinctive humour but also due to his political attitudes and rejection of censorship of any kind. This relationship was crowned by a personal meeting of the Czech underground with Zappa during the artist's first visit to Prague immediately after the Velvet Revolution on January 20 - 24, 1990.59

The founder of the Frank Zappa fan club, Bohumil "Bohouš" Jůza (b. 1954), first learned about American counterculture in 1969, when, thanks to his father, who worked in Egypt for the air defence, he received a yearbook from Life magazine with the celebrated photograph of the Mothers of Invention with infants as part of an article on California hippies. A year later, as a student at the Brno High School of Applied Arts, Jůza became acquainted with Zappa's first recordings, which were brought from the United States before the occupation by the father of one of his classmates. Even at the turn of the 1970s, Jůza perceived Zappa's work, in light of the then fashionable hard rock, as something "weird", but he completely fell in love with it after returning from his military service in 1975, when he bought the original first edition of Hot Rats (1969): "We played it at the party the whole evening, just again and again... There was no going back from there,

55 BŘEČKA, Jan - TUČAPSKÝ, Vladimír. Beatles v Čechách: přehled písemných a fotografických materiálů o Beatles v českých tiskovinách z let 1963 - 1970. Ostrava : Komers, 1998.

56 RIEDEL, Jaroslav. Vliv Franka Zappy na skupinu The Plastic People of the Universe. In PAPOUŠEK SKALICKÝ 2016, pp. 111-117.

57 KOTEK, Josef. Paradoxy z Essenu. In Hudební rozhledy, 1968, Vol. 21, No. 20, p. 630.

58 KOTEK, Josef. Underground Music a její sociální otazníky. In Melodie, 1969, Vol. 7, No. 2, p. 37.

59 PAPOUSEEK - SKALICKÝ 2016, pp. 181-224. 
moreover, when the accident brought me a friend Václav Válka, who was getting loads of records from Germany. It was possible to order anything from him then, and within a month, a novelty-smelling record (for a third of my salary, of course) was in my hands. And there we went... Absolutely Free (1967), 200 Motels (1971), Chunga's Revenge (1970), and my beloved Fillmore East - June 1971 (1971). From that moment on, I needed more than just music. Information, information and more information ..." ${ }^{\prime 60}$ As a result, Jůza soon established personal contact, with a regular exchange of recordings and other materials, with Petr Dorůžka. In addition, penpals were essential: as soon as an ad appeared in one of the periodicals (Melodie, Gramorevue, Mladá fronta, printed materials of the Young Music Section, etc.) saying "I will sell Zappa or I will buy Zappa..., I would write immediately". ${ }^{61}$ During the normalization period, rockers who collected information usually had more steady correspondence acquaintances, while the contact proceeded mostly at a distance and physical meetings took place only occasionally, sometimes after years of exchanging letters. It was on this basis that the extensive social network of the later Frank Zappa fan club was established, covering a number of places in Czechoslovakia and partly abroad. Even in the second half of the 1970s, however, no one was apparently on the lookout for a fan club as such - fan clubs were not "in" at that time. ${ }^{62}$

As was the case with Petr Gratias, Bohumil Jůza was also characterised by a comprehensive approach to the object of his interest, including a deep affection for music and the creator's personality, a desire for maximum possible knowledge related to the given artist, and last but not least, the desire to pass on the information to other people. It is of importance to mention here the renowned Club Brno IV, Křenová 75 "Esenc", operating under the Socialist Union of Youth (SSM) organization, where Jůza on September 22, 1978, at the invitation of the talented artistic leader Vlad'ka Smýkalová (later Smutná), presented an hour-long listening programme about Frank Zappa and Captain Beefheart during the opening of his cartoon humour exhibition. The success of the show immediately established a tradition that lasted in Křenová for almost the entire 1980s. The premiere of the first three-hour long listening show entitled Francis Vincent Zappa on December 8, 1978, was exceptionally well received: "We expected only friends to come, but it was crowded, people were standing, about two hundred of them. The boys from Progress and Synkopy, the legendary local bands, arrived, simply everyone who meant something in music in Brno."'63 Over the following years, an extensive six-part series about Zappa was gradually created, which was often shown on successive days (in renewed premieres and reruns) in related clubs not only in Brno, but also in other cities of Bohemia (Hradec Králové, Jihlava) and Moravia (Olomouc, Hodonín, Prostějov, Blansko). The entire series about Zappa was also presented in the discussed club in Hušovany in $1987 .{ }^{64}$

60 PAPOUŠEK - SKALICKÝ 2016, pp. 162-163.

61 PAPOUŠEK - SKALICKÝ 2016, p. 163.

62 Interview with B. Jůza from September 2020, author's archive.

63 Interview with B. Jůza from September 2020, author's archive.

64 Zappostrophe, March 1987. The fanzine is stored in the private archive of B. Jůza. 
While the Beatles fan club was established on the outskirts of Brno in a relatively short period of time under the neutral designation of "friends of music", the constitution of the Frank Zappa fan club, as a regular institution of its kind without any evasive manoeuvres, took several years. The initial impulse was brought by Jůza's acquaintance with Milan "Gogo" Krampota through an advertisement in Melodie at the beginning of the 1980s. Originally from the Moravian city of Olomouc, but since the end of the 1970s an emigrant in Vienna, Krampota was supposedly the biggest collector of Zappa's artefacts in Europe and even rented an entire flat in the Austrian capital for his collection. He became not only the main supplier of exclusive material, such as bootlegs, books, etc. but also a mediator of contacts with the American artist himself. Krampota first met Zappa in person after his concert in Vienna in June 1982, when he and his friends tracked him down at the Imperial Vienna Hotel. Closer contact came about, however, after the subsequent concert in Linz, after which Czech fans spent about an hour with the artist: "Frank was very interested in the reasons for our emigration, but also in how people live in a Communist state." ${ }^{\prime 65}$ The relationship developed over the following years, and thanks especially to Krampota, resulted in the already mentioned first Zappa visit to Prague after the Velvet Revolution. ${ }^{66}$

As early as 1982, the club had an emblem, created by Jůza's friend and graphics collaborator, Jaroslav Kobylinský, which carried the text 'FRANK ZAPPA'S FAN CLUB, Brno Czechoslovakia". ${ }^{67}$ The emblem was originally made as an appendix to a letter to Frank Zappa, in which Brno fans naively asked the American musician if they could even start a club with his name. ${ }^{68}$ According to Jůza, however, the conditions for the actual establishment of the club were still unsuitable due to the rock trials taking place in Czechoslovakia: an attempt to liquidate the Czech new wave in 1983, to dissolve the Jazz Section in 1984, to abolish the original editorial staff of Melodie magazine in 1984, etc. The actual constitution of the Frank Zappa fan club did not take place until four years later and without any legal registration, as Jůza recalls: "In September 1986, together with the passionate Plzeň Zappist Vašek Pěnkava and a native of České Budějovice - now inhabitant of Brno - Evžen Cyrner, we officially founded a club in Vyškovská pub in Brno, and symbolically prepared the first issue of our fanzine for December."169

While the club in Hrušovany worked mainly with the format of educational listening programmes which took place in a local wine bar and later focused even outside the history of the "Fab Four", the Frank Zappa club concept was primarily based on the idea of sharing individual private archives, with the club fanzine Zappostrophe supposed to become a kind of "superarchive" in this regard. In the first phase, the club's founders selected 30 devoted Zappists and conse-

65 PAPOUŠEK - SKALICKÝ 2016, pp. 176-177.

66 An interview with Krampota about the "real background" of Zappa's visit to Prague in 1990 was published in Zappostrophe No. 129 from 2014. Archive of B. Jůza.

67 The emblem and other materials, including the covers of the Zappostrophe fanzine, can be viewed on the older website https://zappa.mypage.cz/menu/historie-klubu; the new one is available at https://zappa-mypage2.webgarden.cz/rubriky/fan-klub-franka-zappy

68 Interview with B. Jůza from August 2020, author's archive.

69 PAPOUŠEK - SKALICKÝ 2016, p. 164. 
quently expanded the number to 50 in 1988 . The members of the club came literally from all over Czechoslovakia (Aš, Cheb, Mariánské Lázně, Plzeň, Prachatice, České Budějovice, Česká Lípa, Prague, Liberec, Hradec Králové, Pardubice, Jihlava, Třešt', Olomouc, Ostrava, Brno, Břeclav, Hodonín, Bratislava, Nové Zámky, etc.). The original limited number of members was related both to the caution towards the state authorities and to the possibilities of printing the fanzine. The fact that the magazine would be freely copied among the community of each individual member, and thus an extensive secondary layer of Zappostrophe's readers would gradually emerge, was expected from the beginning.

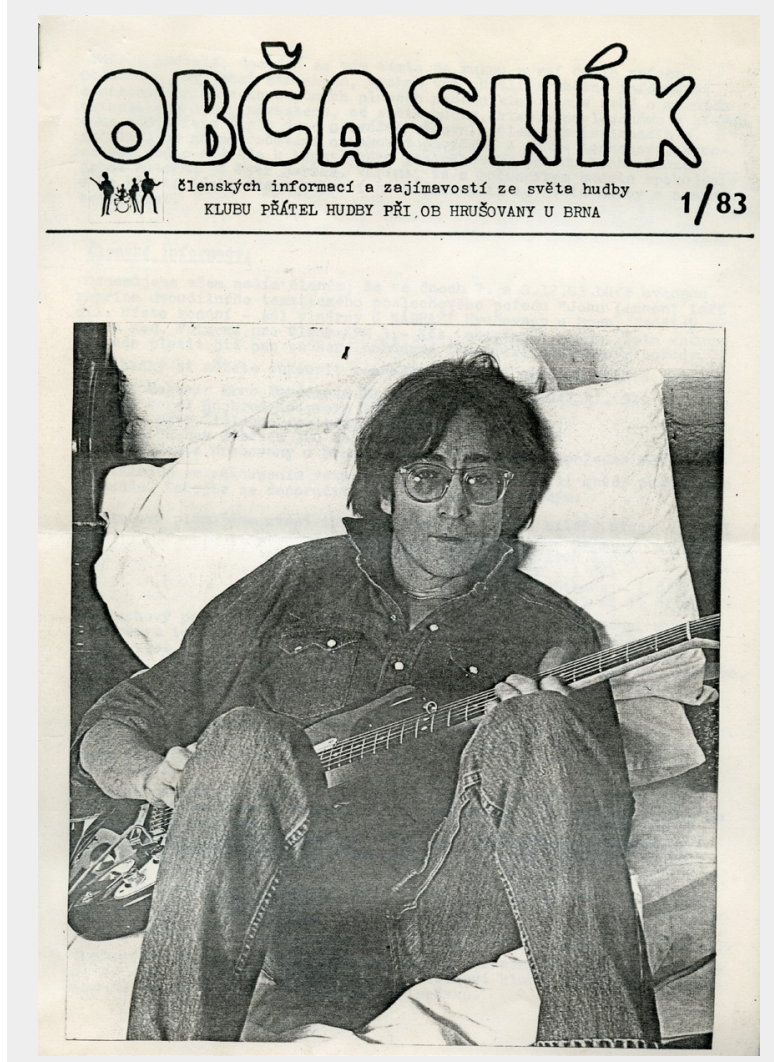

Figure 6 (left). The first issue of Občasník. Archive of J. Břečka

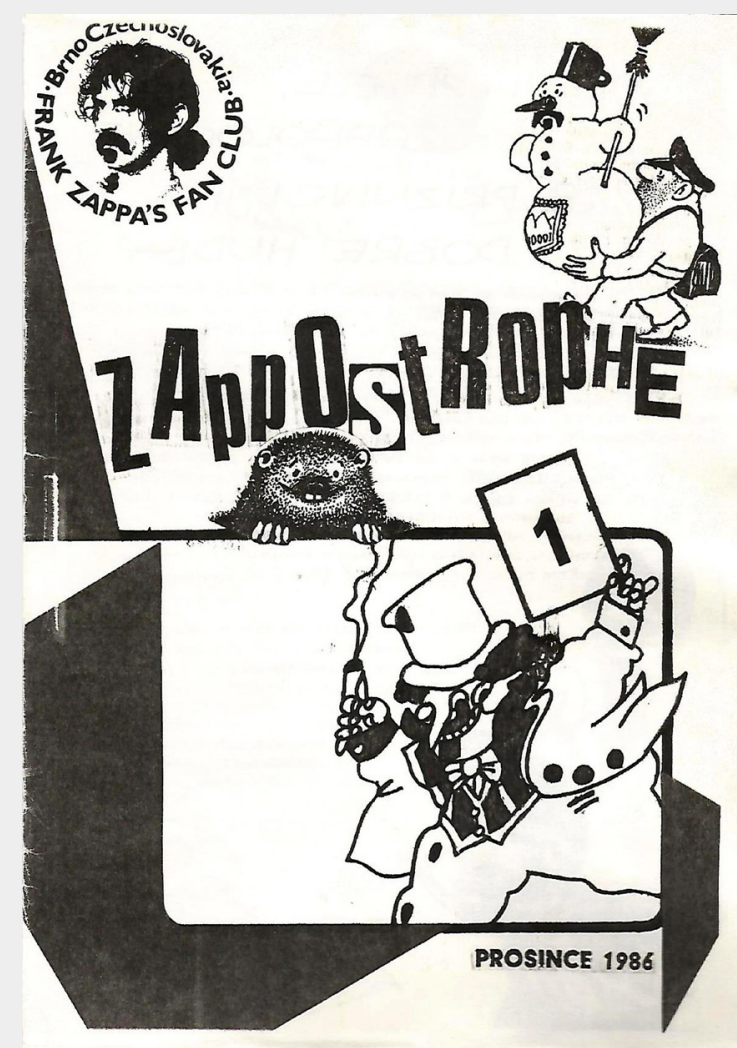

Figure 7 (right). The first issue of Zappostrophe. Archive of $B$. Jưza

While Občasník presented a purely informational publication with a predominance of standard typescript text and only occasional photographs or comics, Zappostrophe emphasized the artistic component based on the style of Zappa's album covers, in some respects anticipating the playful graphic design of punk and the new wave: "We didn't want to multiply it on a cyclostyle or ormig, or rewrite materials on typewriters. It had to have a dense, high-quality, unlimited content and graphic form that would ideally correspond to the cover expression of Cal Schenkel, especially the pictures and photographs."70 Before 1989, Zappostrophe was copied unofficially through Xerox in a photographic services company in the centre of Brno: "At first they quibbled a little bit, whether we had a stamp of the organization and such, but in the end we became friends with the women 
working there, so it was done in a big way. The girls received Tuzex candy boxes, they did it after working hours. ${ }^{\prime 71}$ The club's fanzine was published irregularly and to a varying extent, always at a time when, thanks to various domestic as well as foreign contributors, a sufficient amount of material was collected. While the first issue from 1986 only consisted of two double-sided A4 sheets folded in half, the Zappostrophe EXTRA 1989 yearbook contained over 80 pages. $^{72}$ The material was organized thematically and supplemented by general information and smaller reports, as needed. The frequency of publication was relatively stable until 1990: 1986 ( 1 issue), 1987 (10 issues), 1988 ( 8 issues plus 1 special), 1989 ( 8 issues plus 1 extra yearbook), 1990 ( 8 issues plus 1 extra yearbook and 1 collection of illustrated translations of lyrics). The turning point came in the following years, when the club, under the influence of general changes, actually disintegrated for some time.

The technique of gluing cuttings to paper and subsequent copying with Xerox resulted in a dynamic look, an asymmetrical combination of various text and image fields as well as humorous intertextual puns. In the magazine, photocopies of domestic and foreign texts from various sources - articles, interviews, reports, or just the subtitles (in German, English, but also French, Spanish or Italian) freely intertwined and overlapped; further, there were typewritten and handwritten texts (original or adapted), photographs, drawings, cartoon jokes, comics, etc. In a sense, the magazine was a clippings chronicle, which many avid rock listeners were already frequently creating in the 1960s. In this case, however, such an archive was transformed into a higher form of shared medium, while at the same time being an artefact that has its own specific social history. Thematically, Zappostrophe focused mainly on the history of Frank Zappa (detailed descriptions of records, translations of lyrics, analyses of pirate recordings, concert tours, album covers, the history of Zappa's teammates, such as Captain Beefheart, etc.); the artist's history in Czechoslovakia was not omitted, though (the history of listening programmes in the Křenová club, the history of the fan club itself, original interviews with Czech artists and Zappa, club polls, discussions and record exchanges, specific sections, such as "Zappa through the eyes of our women", Zappa's visit to Prague, etc.). Naturally, the magazine also reported on purely club matters, including regular "congresses" of Zappists in various parts of Bohemia and Moravia, which were also occasionally discussed in Melodie. ${ }^{73}$

For the first year, the membership fee of the Zappa fan club was set at 100 crowns, which was to cover the reproduction of the magazine, translations of foreign texts, photographs or postage; in 1989, the annual fee was increased to 200 crowns. Special supplements were paid separately to order, which also applied to the audio materials that the club released for the needs of the members on its own label Motyčkovy Kazetky. Already in the first issue of Zappostrophe, 90-minute cassettes with selections from the best concerts and bootlegs were promised; between

71 Interview with B. Jůza from August 2020, author's archive.

72 PAPOUŠEK - SKALICKÝ 2016, p. 165.

73 OPEKAR, Aleš. 5. Frank Zappa's Fan-Club Congress. In Melodie, 1990, Vol. 28, No. 1, p. 15. 
1987 and 1998, 13 titles were finally released, some of which even had three cassettes. ${ }^{74}$ VHS joined the cassettes in 1990, and afterwards the club switched to CD and DVD publishing. As with Občasník, Zappostrophe is not currently registered by the Libri Prohibiti library, and in connection with Czech musical samizdat, it is not mentioned by the authors of summary works on domestic rock, such as Miroslav Vaněk. ${ }^{75}$

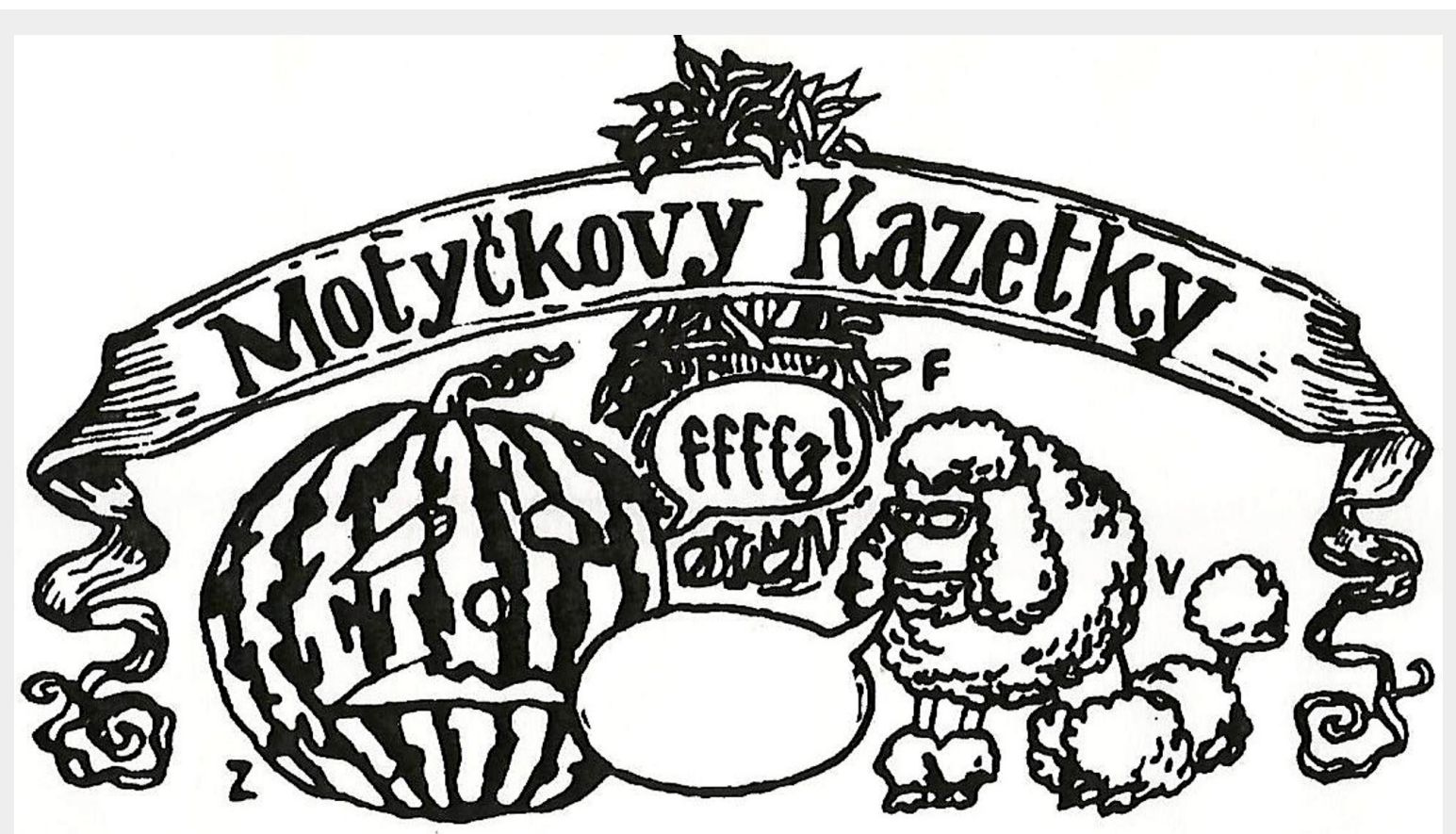

Figure 8. Motyčkovy Kazetky label. Archive of B. Jůza.

\section{Conclusion}

The history of both Brno fan clubs reveals a number of remarkable facts. In a narrower sense, it is the specific tradition of the Beatles and Frank Zappa fandom in Czechoslovakia and the mutual relationship between the two communities. In connection with the era of normalization, Jiři Černý characterised Zappists as "the cutest, because there were the fewest of them". ${ }^{76}$ Probably no one has ever described the much larger and therefore more diverse community of Beatles' supporters in this way; however, in the international context, it is sometimes generally associated with "the most amazing people". ${ }^{77}$ Within the Brno scene, both the Beatlephiles and the Zappists knew each other well; they were often friends or comrades of friends, visited the same pubs, and met regularly at concerts and record exchanges. The founders of both clubs represented typical rock aficionados, ${ }^{78}$ who shared the same generational experience, in which the legacy of the 1960s resonated strongly, as it entered the culture of the Central European country and the Moravian region. According to Petr Gratias, a certain number

\footnotetext{
74 PAPOUŠEK - SKALICKÝ 2016, p. 168.

75 VANĚK 2010.

76 Czech television series created in 1995 - 2000, Bigbít, episode 19.

77 Cf. the entry "Beatles fandom" at Urban Dictionary, https://rb.gy/1jl8ex

78 SHUKER 2005, p. 99.
} 
of people "rode on the train where the Beatles were listened to, Jaroslav Foglar and Karl May read, where Zdeněk Burian and Kája Saudek were perceived, so when these people with these views met, a diverse mix of debate circles arose. ${ }^{\prime 79}$ In fact, Jules Verne's novels with Burian's illustrations and Kája Saudek's "insurmountable" comics at the very least also shaped the artistic experience of the Zappist Bohumil Jůza.

There were also peculiar confrontations between fans of the Beatles and Frank Zappa, which were not meant as hostile, but instead reflected the different poles of taste and reception of rock (especially the relationship to humour and irony in rock and its possible socio-critical function). Petr Gratias recalls how the Zappists would ironically ask him: "So, are you still listening to 'she loves you, yeah, yeah, yeah?'"'B0 According to Jůza, ironizing "the best band ever", the Beatles, belonged to local folklore and humour, over which listeners from Prague were even puzzled. Not only fans of the Beatles, however, ridiculed the Zappists for building a cult of personality and fetishism, for example, in the form of archiving Zappa's cigarette butt from the artist's visit to Prague. When the Zappists appeared at the Brno record exchange, the sellers would say straight away: "Hide it, they don't understand it, they only listen to Zappa." The Zappists usually replied: "Wrong, we listen to everything to hear everyone play worse than the Master."11

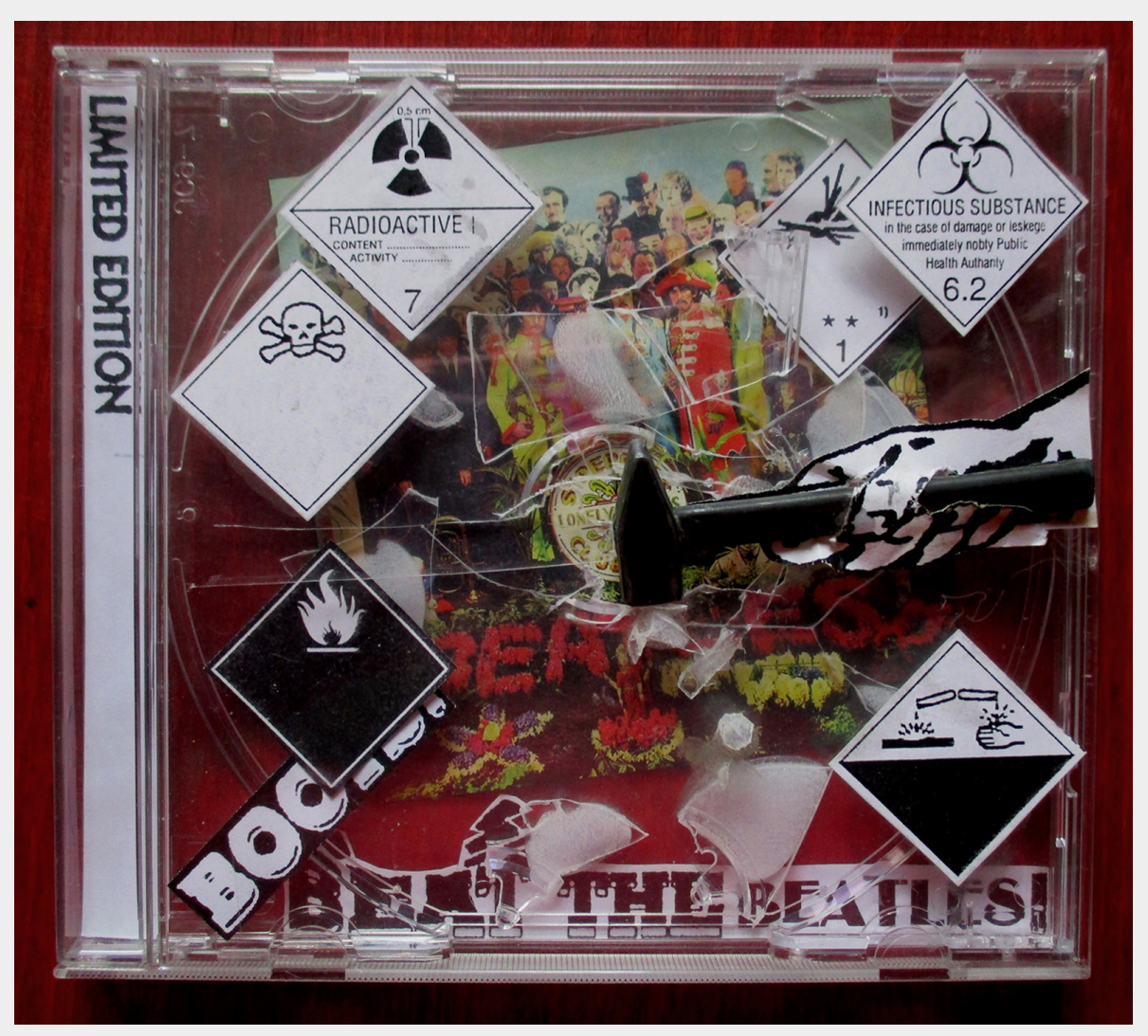

Figure 9. Zappart Beat the Beatles! by Bohouš Jůza. Archive of B. Jůza.

79 Interview with P. Gratias from June 2020, author's archive.

80 Interview with P. Gratias from June 2020, author's archive.

81 PAPOUŠEK - SKALICKÝ 2016, p. 162. 
On a more general level, the history of Brno fan clubs illustrates the development of Communist cultural policy in relation to Western popular music from the era of political causes with rock in the early 1980s to the relative benevolence of the authorities at the end of the same decade. Although the motivation to establish a fan club in both cases existed as early as 1982, overcoming the traditional format of club listening programmes towards an autonomous fan club with an adequate name, with an overlap abroad, including contact with the admired artist, with distribution of recordings and a fanzine, which is not just a reporting outlet but which also fulfils additional artistic and social functions, was only managed by the Zappists after 1986. In terms of the concrete manifestations of state cultural policy, however, Brno and thus the entire Moravian scene displayed certain specifics. As Jana Soukupová claims: “During normalization, Brno's advantage was that the political bodies based here always preferred a dialogue over confrontation." ${ }^{\prime 2}$

Mikoláš Chadima recalls, for example, how Frank Zappa was perceived in the Prague, the capital of Czechoslovakia: "We started with his music, we played him with the Electric Bus band, and we were chased by the police because of that. I really remember the interrogations at the StB, when the police shouted at us: 'We'll get that Zappa out of your head!' He was apparently considered a political and ideological ruler or some head of an anti-communist diversion centre. So Zappa represented this for our generation who played it."83 Conversely, this was not the case for rockers in Brno, who regularly introduced Zappa's music to the general public through the listening programmes in Křenová club, which were also reported on in the official press. According to Jůza, Brno was a large village where everyone knew each other and got along well together: "After the Saturday music exchanges, we met at the pub called U Formana, where friends from Charter 77, including Petr Cibulka, usually sat with us. The secret StB officers also visited the place; we recognised them, and we knew that they wouldn't say anything. When we got drunk, we always quarrelled and shouted at each other: 'You fucking Chartist!' or 'You fucking Zappist!' It was just fun."84

If we compare Brno with Prague, the specific processes of the institutionalization of the Beatles fan communities in both cities during the 1980s were also quite symptomatic. While in Brno the Lennon cult stood at the beginning of the fan club in Hrušovany, which was always focused exclusively on music, in Prague, the Lennon tradition resulted in the constitution of the John Lennon Peace Club in 1988, with primarily political goals.$^{85}$ In this sense, the scene in Brno considerably challenges the frequent interpretation of post-communist historiography on rock in Eastern Europe as political music par excellence, as has already been indicated in connection with the concept of Ewa Mazierska in the introduction to this text. This eventually touches on other related interpretive stereotypes, such

82 SOUKUPOVÁ, Jana. Zázrak jménem Revue 88 aneb Když samizdat dělali studenti. In iDNES.cZ, 28 March 2010, https://rb.gy/sxxfgk

83 PAPOUŠEK - SKALICKÝ 2016, p. 215.

84 Interview with B. Jůza from August 2020, author's archive.

85 The club's archive is stored in the Libri Prohibiti library. 
as "rock as a place of escape from normalization greyness" or "normalization and its information vacuum regarding Western popular music." 86

The fact that long-term fan clubs of representatives of Anglo-American popular music at the time of normalization are not documented in the Czechoslovak capital may be related to a number of factors: among other things, the level of information background and general knowledge of the local rock community as an important prerequisite for the motivation to build musically defined social networks, the level of local repression, etc. In addition, the fact that the potential founders of specific fan clubs in Prague were integrated by more widely conceived educational institutions in the field of alternative or less available popular music genres, such as the Jazz Section or the Young Music Section, played a role. ${ }^{87}$ The founders of the Brno fan clubs were members of both Prague institutions; however, they developed their musical-popularization model in their region in an original way - in the spirit of Petr Hrabalík's thesis that the most remarkable things that appeared in Czech rock in the 1980s came from Brno. ${ }^{88}$

There is currently no evidence of the Frank Zappa fan club's existence in neighbouring Communist countries. The situation was different, however, in the case of the Beatles, who had a fan club in Lublin, Poland, in the early 1980s. Thanks to this club, it is possible to compare similar activities not only on the Brno - Prague axis, but also the Czechoslovakia - Poland axis. The number of common denominators between Brno and Lublin is remarkable: a similar population, a similar relationship to the capital (including typical connotations of the "centre" - "periphery" polarization), a similar position within the country's geography, a lively rock scene, etc. The Beatles official fan club in Lublin was established in October $1982,{ }^{89}$ a month before the inaugural meeting of the fan club in Hrušovany. Although both clubs were established at a time of increased cultural restrictions (Poland saw the introduction of martial law in 1981 - 1983), they sought to have an official status. Both clubs were founded by members of the second rock generation - in Lublin it was Krzysztof Jan Werner (b. 1960), only five years younger than Petr Gratias. The starting point in both cases was the death of John Lennon; in both cases, the fan club was quite exceptional in the context of the whole country. The common denominator was also the emphasis on concentrated and intense musical enlightenment without any political ambitions.

Not only the similarities, however, attract attention. The Lublin fan club also dealt with a number of administrative problems during its existence, eventually even achieving higher goals partly as a result of the more accommodating relationship of Polish cultural policy to popular music. The club managed to take part, for example, in the Beatles' international fandom, and despite the Iron Curtain, established contact with primary institutions in Great Britain. From the point of view

86 Cf. TV series Bigbít.

87 KOUŘIL, Vladimír. Jazzová sekce v čase a nečase. Praha : Torst, 1999.

88 HRABALÍK, Petr. Brněnská alternativní scéna. In Internetová encyklopedie rocku Bigbít, https://rb.gy/ bdkaeo.

89 WERNER, Krysztof Stanisław. Działalność Fan Club-u The Beatles w Lublinie w PRL-owskiej rzeczywistości lat 80. Lublin : Uniwersytet Marii Curie-Skłodowskiej W Lublinie, Wydział Politologii, 2014, p. 63. 
of Communist Czechoslovakia, the promotion of the Lublin fan club in the Polish media, including a programme dedicated to the Beatles by Piotr Metz which had been broadcast by Polish Radio Program III since 1982, seems to be a completely unseen fact. One should add that the programme could also be tuned into in the North Moravian region, thanks to which the Lublin fan club gained a number of members from Czechoslovak towns such as Karviná, Třinec, Opava, or Bruntál. At the end of the 1980s, the Lublin fan club had more than 500 members (of all ages, but mostly aged 15 - 35), including fans from East Germany and the Soviet Union..$^{90}$ Both fan clubs ceased operations in 1990: the one in Lublin for economic and administrative reasons, the one in Brno - as mentioned earlier - due to the death of the leading personality Cyril Fanta.

Jiří Černý's article "Beatlemania in Czech and Slovak" was published in 2008, which indicates the important role played by Beatles' fandom especially in the eastern parts of the country. The author argues that the Prague performance of the Bratislava band the Beatmen in 1965 brought us all to the Beatles in the most radical and best way. Out of a range of unofficial normalization publications about the Beatles, Černý mentions the beautifully bound samizdat text by the Bzenec rock "missionaries" Pavel Hanák and Jan Grombíŕ, and views the song by the Association of Friends of Mild Humour If John Lennon was from Moravia as the most original of all South Moravian Beatles' inspirations. The article naturally also mentions Hrušovany near Brno, which the author called a "fortress of true Beatles' enthusiasts. ${ }^{91}$ In this regard, it is remarkable that the first officially registered fan club of the Beatles in the post-communist era, which some of the members of the original institution in Hrušovany also joined, was established in the North Moravian Region in Ostrava in $1994 .{ }^{92}$ A Beatles' fan club is also documented at that time in the Slovak town of Nitra. ${ }^{93}$

The immediate post-revolutionary development of Frank Zappa's fan club brought a short-term increase in the membership base up to 168 people, caused mainly by the artist's media attention during his stay in Prague in 1990, followed by its official registration by the Ministry of the Interior. There was finally also the actual disintegration of the club under the influence of general changes: "We all began to carry out our personal plans, some still celebrating freedom, others doing business, stealing, engaging in politics, doing drugs, trying out various dubious religious associations, travelling abroad to work."94 From 1991 to 1995, the Zappostrophe was published only minimally and there were no regular club meetings as in the past. The search for sponsors was not particularly successful, as the original media interest in alternative music, including all the accompanying phenomena, began to decline significantly after $1992 .{ }^{95}$ As occurred to other

90 Correspondence with the president of the re-established Beatles fan club in Lublin Krysztof Stanisław Werner from September 2020, author's archive.

91 ČERNÝ 2008.

92 Cf. the fanzine Beatles včera a dnes published in 1994 - 2000, available at the state libraries.

93 Fankluby ve světě. In Beatles včera a dnes, 1994, Vol. 1, No. 1, p. 18.

94 PAPOUŠEK - SKALICKÝ 2016, p. 171.

95 Cf. the document by Czech television Ladí, neladí (2006) with Marián Varga and Mikoláš Chadima as guests. 
creators of pre-revolutionary samizdats, the new copyright context did not allow the Zappists to implement the plan for the official publication of the Czech translation of the crucial The Real Frank Zappa Book (1989); the translation was finally published in 1995, albeit in an unsaleable volume of only 100 units, which later became a sought-after rarity for collectors. ${ }^{96}$ In this sense, the renewed Frank Zappa fan club with a membership base of no more than 50 people returned to its original underground existence in the following years, ignoring any calls from the authorities and without any obligation to deal with mandatory copies for state libraries. ${ }^{97}$

96 PAPOUŠEK - SKALICKÝ 2016, p. 170.

97 Interview with B. Jůza from August 2020, author's archive.

Cite:

Blüml, Jan. Beatlephiles and Zappists: Rock Fandom in Communist Czechoslovakia in the Context of the Scene in Brno in the 1980s. In Forum Historiae, 2020, Vol. 14, No. 2, s. 63-57. ISSN 1337-6861. DOI: https://doi.org/10.31577/forhist.2020.14.2.3

Mgr. Jan Blüml, Ph.D.

Katedra muzikologie

Filozofická fakulta

Univerzita Palackého Olomouc

Univerzitní 3, 77900 Olomouc

Česká republika

E-mail: jan.bluml@upol.cz 